\title{
RESTRIÇÕES E CONCESSÕES AOS DIREITOS DOS ESTRANGEIROS
}

\section{Oscar Martins Gomes}

Professor de Direito Internacional Privado da

Faculdade de Direito da Universidade do Paraná

Súmula. - 1. O estrangeiro na Antiguidade Oriental. - 2. Na Grécia. - 3. Em Roma. - 4. Com a invasão dos Bárbaros. - 5. No Feudalismo. - 6. No Municipalismo e na fase dos Estatutos. O Liberalismo Inglês. Tempos Modernos. - 7. Os primeiros Códigos Civis. - 8. O Brasil no Império. A Constituição de 1891 e o Código Civil de 1916. 9. As restrições para o estrangeiro na Constituição de 1946. - 10. 11 e 12. Mais restrições nas leis ordinárias. - 13. Outras limitações na legislação comum. - 14. Regulamentação da vida do estrangeiro no País. - 15. Estrangeiros "residentes" no País. - 16. Estrangeiros "não-residentes". Direitos supraestatais. - 17. Direitos "voluntários" e "públicos". - 18. Direitos "públicos não políticos" e "direitos privados". - 19. O Código Bustamante, arts. $1 .^{\circ}$ e $3 .^{\circ}$. A Convenção de Havana de 1928 sôbre a Condição dos Estrangeiros, art. 5.': "garantias individuais" e "direitos civis essenciais". - 20.A lei competente no direito internacional privado. - 21. De jure constituendo. - 22. Declarações de Direito nas Constituições modernas. A Carta Americana de Bogotá. - A Declaração Universal dos Direitos do Homem, da O. N. U., em 1948.

Aula inaugural do ano letivo da Faculdade de Direito da Universidade do Paraná, proferida em março de 1956, por designação da respectiva Congregação. 
Estrangeiro é o indivíduo fora de sua pátria, ou então: é o indivíduo estranho a determinado sistema jurídico, mas que acidentalmente dêle participa, - conceitos simples, mais apropriados ao desenvolvimento da presente dissertação, cujo objetivo é recordar como tem sido tratado o estrangeiro através dos tempos, desde a antiguidade oriental, mostrar com detalhes a conduta jurídica do Brasil a êsse respeito e examinar os limites das restrições que podem ser impostas ao estrangeiro na comunidade internacional.

1. Na India, na Média e na Pérsia, no Egito, países da mais remota civilização no velho oriente, o estrangeiro era olhado com desprêso, como ser amaldiçoado, inferior, destinado à escravidão e ao trabalho braçal, não havendo crime em matá-lo. Na India, o estrangeiro nem figurava entre as castas; permanecia como um pária, fora da sociedade bramânica, privado de direitos religiosos e sociais, classificado abaixo dos elefantes e dos cavalos. A religião de Zoroastro lhe votava inteiro repúdio. No Egito, para o bruto labor da construção das famosas pirâmides, serviam de escravos os estrangeiros e, a propósito, na mais alta delas, foi lançada a inscrição: "Nenhum homem do país trabalhou neste monumento", como aviso jactancioso à posteridade.

$\mathrm{Na}$ China, a prevenção contra o estrangeiro foi abrandada com os ensinamentos de bondade e tolerância de seu filósofo e reformador Confúcio, santo e sábio, que mandou tratar bem e humanamente as pessoas vindas de longe.

Entre os Hebreus acentuou-se o espírito de hospitalidade, graças à instituição do prosselitismo, que era de justiça quando o estrangeiro adotava a religião mosaica e se submetia à circuncisão, equiparando-se aos filhos de Israel, e de domicílio quando a integração na nacionalidade se operava apenas com a residência no país.

2. Na Grécia, segundo a expressão do historiador latino Tito Livio, ao dizer que com os alienígenas, com os bárbaros, ela estava em eterna guerra, o estrangeiro era mal visto. Ate- 
nas, mais culta e de mais comércio e, portanto, cultivando mais relações com o exterior, dispensava ao estrangeiro melhor atenção do que as outras cidades. Ali eram os estrangeiros divididos em três classes: os isóteles, gosando de certos direitos e regalias, mais se aproximavam dos nacionais; os metecos, que sofriam mais restrições nos seus direitos, não podendo adquirir bens imóveis nem casar legitimamente com ateniense; e os bárbaros, que não faziam jus a proteção alguma e eram considerados fora da civilização. Para assistência aos estrangeiros, a história registra a criação de magistrados especiais, e tais eram os Sicofantas, que se celebrizaram como opressores e corruptos; os Polemarcas e, abaixo dêles, os Proxenas. Certas repúblicas gregas concediam ao estrangeiro o direito de cidade, com restrições estabelecidas. Outras lhe localizavam o domicílio em determinada parte, sob vigilância.

3. Em Roma, nos primitivos tempos, o estrangeiro era o hostis, o inimigo, o advindo de países em guerra com os romanos. Para regular as relações dos estrangeiros entre si e dêles com os cidadãos romanos, foi-se formando um corpo de regras comuns, provenientes de editos dos pro-cônsules. Era o jus gentium, sem as características do moderno direito das gentes, significativo do direito internacional, mas abrangendo os preceitos elementares do direito natural, ditados pela razão natural e que não podem deixar de ser observados nas relações humanas. Recebeu então o estrangeiro a denominação mais benevolente de peregrinus. 0 proetor peregrinus era o magistrado que aplicava o jus gentium. Nêsse regime, que durou séculos, antes da era cristã e nesta vedava-se aos estrangeiros contrair núpcias, suceder, exercer o comércio, tornar-se propiretários e recorrer das decisões do juiz no uso do jus provocationis.

Nas relações dos cidadãos romanos entre si vigorava o jus civile, aplicado pelo proetor urbanus. 0 jus civile, expressão literal de direito da cidade, passou a significar o direito especial do povo, da nação, nas relações de ordem privada entre os cives romani. Os peregrinos latinos, isto é, os habitantes do Latio, região próxima à cidade de Roma, gozavam de mais di- 
reitos do que os peregrinos ordinários. Mas, a aquisição da qualidade de cidadão romano só dificilmente era conseguida.

A lenta extensão de direitos aos estrangeiros logrou sua etapa mais eficiente no começo do terceiro século da nossa era, quando o imperador Caracala, conquanto se houvesse notabilizado por sua tirania e seu feitio sanguinário, a ponto de mandar matar milhares de pessoas entre as quais o notável jurisconsulto Papiniano, proclamou a igualdade entre os estrangeiros e os cidadãos romanos, com a declaração de que "in orbe romano qui sunt cives sunt romani".

RODRIGO OCTAVIO, cuja obra tão útil nos tem sido na bibliografia consultada nesta parte histórica, assim comenta êsse magno acontecimento: "Desde então, nos vastos domínios do Império Romano, que havia estendido sua soberania sôbre quasi tôda a parte politicamente organisada do continente europeu, a civitas não foi mais do que um elementos do status. Dêsse princípio só se excetuavam os bárbaros, que se sabia vivendo em enormes e temerosas legiões no sombrio maciço do centro, do norte e do oriente da Europa. Êsses, quando isoladamente penetravam no território do Império, não gozavam mesmo do benefício do jus gentium. Suas pessoas não mereciam proteção legal de espécie alguma; podiam ser mortos ou escravisados; seus bens eram rs nullius; sua sepultura não era res religiosa. Uma constituição do Imperador Valentiniano proibiu, sob pena de morte, o casamento de um bárbaro com um romano. Enfim, segundo a pitoresca expressão de Ortolan, êles viviam "fora da civilização e da geografia". ("Dir. Int. Priv. ${ }^{\circ ",}$ P. G., pág. 41).

4. Mas, a êsses bárbaros assim tão execrados, estava reservada a missão histórica da invasão e da conquista na fase da decadência do Império Romano. Os Germânicos passaram a dominar a Gália e a península itálica. Levaram sua leis próprias mas não se opuzeram a que os povos por êles dominados se regessem por sua próprias leis. É de se imaginar o que seriam então aqueles grandes aglomerados humanos, com gente provinda de regiões diversas, grupos étnicos diferentes, em 
áreas territoriais sem delimitação de fronteiras, como consequência da ocupação germânica dêsse modo precipitada.

Tal situação deu lugar ao individualismo pessoal gerando o período histórico da personalidade das leis, que começou pela discriminação do direito germânico para as tribos invasoras e do direito romano para os vencidos. Depois, os povos que foram tomando os nomes de francos, lombardos, burguinhões, no território próprio ou no entrelaçamento dêles ocasionado pelas relações de comércio e outras, emprestaram mais efetividade a êsse sistema. Adotaram-se as professiones legis, para saber a que povo ou tribo pertencia a pessoa titular de um direito, indagando-se dela: sub qua lege civis, a fim de aplicar-lhe sua lei.

Observa BLUNTSCHLI: "Atraz do estrangeiro os Germanos viam sempre o homem, e achavam equitativo que cada um fôsse julgado segundo o direito de sua tribo de origem ou da tribo que êle tinha adotado. Reconheciam assim a coexistência dos diferentes direitos nacionais". (apud R. OCTAVIO, obr. cit., pág. 42).

O sistema da personalidade das leis durou cêrca de cinco séculos. Não obstante, a continuidade da mesma população no mesmo solo, falando a mesma língua, foi formando as novas sociedades étnicas, onde a condição de estrangeiro se fazia sentir aos forasteiros. Daí a instituição do patronato, que consistia na proteção dispensada pelo nacional ao estrangeiro, a fim de que seus direitos fossem respeitados. Ao protetor ou patrono chamava-se recomendatus e ao estrangeiro ádvena ou peregrinus. Para adquirir a situação de protegido e ter seus direitos assegurados, embora civilmente inferior, aplicava-se a máxima então corrente entre latinos, germânicos e britânicos: por duas noites, hóspede; por três noites é havido como da família, e assim o estrangeiro adquiria no seu hospedeiro um patrono.

Mas, essa proteção passou depois, sob o exquisito nome de mundiburdium, a ser exercida pelo Rei, que, em retribuição ao benefício recebido pelo estrangeiro, lhe impunha fortes restrições aos direitos, cobrava-lhe o impôsto especial chamado ga- 
bela, usava do direito regalista de detração, ou seja participação, pela corôa, da herança deixada por êle, e ainda se locupletava com o albinagio, instituição que, assumindo vários aspectos, permitia ao Rei suceder ao estrangeiro falecido sem filhos legítimos.

5. Sobreveiu, para a civilização do Ocidente, o largo periodo histórico do feudalismo, durante o qual, a partir do século dez, passou a imperar, em vez da personalidade das leis, 0 sistema da territorialidade das leis. Os feudos, delimitados e fortificados, numa era de frequentes guerras, tomavam os nome de baronia, condado, castelania, bispado, etc. e ficavam sob o domínio do poderoso senhor feudal. Não se reconheciam direitos ao estrangeiro, submetido sempre às leis do feudo, sem poder invocar as leis de outro feudo ou nação de origem.

Esclarece outro conspícuo jurista pátrio, EDUARDO ESPINOLA: "O sistema da territorialidade absoluta das leis foi uma consequência das causas que haviam criado o sistema da personalidade, e, ao mesmo tempo, da profunda transformação política-social, realizado pelo feudalismo num período em que, predominante o elemento territorial, não havia dentro do território leis pessoais distintas, sendo, por outro lado, muito precária a condição de estrangeiro. É certo que - acrescenta - no regime feudal não se reconheceram direitos ao estrangeiro, como tal. Todo aquele que se afastava da região feudal a que pertencia, para se fixar em outra, era estrangeiro (aubain) (“Dir. Int. Priv.0", pág. 90).

Longe estava de haver igualdade civil em favor da pessoa extranha ao feudo. Ela teria de prestar juramento de sujeição completa ao senhor feudal, que, caso contrário, podia dispor da pessoa e bens do estrangeiro.

O droit d'aubaine e outras instituições, criadas em beneficio do senhor feudal, serviam, em todo caso, para abrandar êsse rigor. O albinagio continuou a subsistir para justificar a qualidade sucessória do senhor feudal ou do Rei, quando mor- 
ria um estrangeiro, a quem não se outorgava o direito de dispor dos seus bens em testamento.

Durou séculos êsse regime. $\mathrm{E}$ tais direitos sôbre os bens dos estranegiros vieram até a Revolução Francêsa. Asseguram entretanto os escritores que o albinagio era desconhecido no direito português, não figurando, portanto, no corpo de leis impôsto ao Brasil até sua Independência.

6. Nesta passagem rápida através dos séculos, novas etapas de progresso, cultura e civilização devem ser lembradas. Sobreveiu o período que se convencionou chamar de municipalismo, sem que, entretanto, deixassem de subsistir, embora em decadência, muitos feudos, com a circunstância porém de maior supremacia dos reis em relação ao poderio dos senhores feudais.

O fenomeno histórico se operou principalmente na Itália, onde as antigas comunas, nos séculos XII e XIII, se transformaram em repúblicas, como Veneza, Genova, Milão, Pisa, Ferrara, Bolonha. O intercâmbio comercial ganhou incremento nessa parte do Mediterrâneo, a par dos estudos superiores, numa revivência da cidade antiga da Grécia e Roma, consoante as eruditas informações de Fustel de Coulanges.

As atividades políticas dessas cidades, a par de seu desenvolvimento econômico, as guerras e alianças, o acolhimento de políticos perseguidos, que buscavam exílio em terras estranhas, novos sôpros de liberalismo social, o influxo do Cristianismo, tudo isso levou tais núcleos a irem consubstanciando regras de legislação local, a par das normas gerais do direito romano, do direito germânico e do direito canônico.

Essas regras locais tomaram o nome de statuti na Itália, coutumes na França, fueros, na Espanha e foros em Portugal. Prevaleceu entre tôdas a denominação de estatutos. E do entrelaçamento de relações, das migrações faceis, situações jurídicas foram surgindo entre pessoas de cidades diferentes, ocasionando conflitos entre os direitos positivos das cidades pertencentes ao mesmo ou a diversos reinos. Advem dessas circunstân- 
cias, na história do direito, a teoria dos estatutos, na qual se notabilizaram tantos jurisconsultos, como os post-glosadores $B A R T O L O$ e BALDO na Itália, DUMOULINS e GUI DE COQUILLE na França, BURGUNDIUS e PAULO VOELT na Holanda.

Conforme a condição jurídica dos bens ou das pessoas, os estatutos se dividiram nas categorias de reais ou pessoais, se se referiam às coisas ou às pessoas, sobrevindo a classe dos estatutos mistos quando se referiam simultaneamente às coisas e às pessoas, depois desaparecida (séc. XVIII) e englobada na categoria dos estatutos pessoais.

A diferença do predomínio do sistema da personalidade das leis, após a invasão dos bárbaros, e do regime da territorialidade das leis no período feudal, em relação à fase estatutária, está em que, nessa fase, enquanto aos estatutos reais se atribuia territorialidade absoluta, aos estatutos pessoais se reconheceu efeito extraterritorial. Isto é, os estatutos pessoais acompanhavam o indivíduo onde êle fôsse, sicut lepra cuti.

Constitui, pois, notável conquista da época estatutária essa de permitir que o ser humano tivesse seus direitos pessoais regidos, onde quer que êle se encontrasse, por suas próprias leis, quer dizer, de sua cidade, de seu Estado.

A condição jurídica do estrangeiro ia assim melhorando pouco a pouco no que respeita aos direitos civis, permanecendo entretanto muitas restrições à sua capacidade. Naturalização, direito de suceder e de testar e outras concessões foram fixados em tratados diplomáticos.

Advem do período estatutário, com a teoria dos estatutos, para derimir os conflitos de leis, o nascimento do Direito Internacional Privado, cujo objeto específico é mesmo estabelecer normas para solução de conflitos entre sistemas legislativos diferentes, quando chamados a resolver determinada relação jurídica.

Novas etapas de progresso geral, o surto luminoso da Re- 
nascença, as conquistas nos campos econômico industrial, as descobertas da ciência, a reação popular contra o absolutismo dos reis e a imoralidade das côrtes, a Reforma de Lutero, o descobrimento do Novo Mundo e do caminho maritimo para as Índias, o liberalismo cosmopolita, os ensinamentos dos filósofos e enciclopedistas do século XVIII, a independência dos Estados Unidos, o notável acontecimento histórico que foi para o ocidente a Revolução Francêsa, tudo isso conduz-nos à idade contemporâneo dentro de uma concepção mais liberal, racional e humana de encarar os direitos dos estrangeiros na comunhão universal.

A Inglaterra, de evolução jurídica própria e pouco acessivel, nos séculos de sua formação, à influência da cultura do continente, plantou marcos exemplares e inolvidáveis na história da liberdade, com a "Magna Charta Libertatum" de 1215, o "Habeas-Corpus Act" de 1679 e o "Bill of Rights" de 1788.

7. O Código Civil da França de 1804, denominado Código Napoleão, pela influência que, em sua elaboração, exerceu o insigne general e estadista, iniciou a série de preciosas codificações do sóculo XIX. As leis locais, os costumes ou estatutos tiveram nêsse monumento sua sábia coordenação, com modificações sensíveis.

Adotando o critério da reciprocidade diplomática, assim dispôs no art. 11, quanto aos estrangeiros não domiciliados no território francês: "O estrangeiro gozará em França dos direitos civis iguais aos que são ou vierem a ser concedidos aos francêses pelos tratados da nação à qual êsse estrangeiro pertencer".

Mas a plenitude de direitos foi outorgada aos estrangeiros domiciliados, conforme art. 13, modificado em 1889, nêste têrmos: "O estrangeiro que houver sido autorizado por decreto a fixar seu domicílio em França aí gozará de todos os direitos civis".

Observam os comentadores que, mesmo independente do 
domicílio e da reciprocidade diplomática, o estrangeiro é tratado com liberalidade nêsse culto país. Não se operou ali a inteira equiparação dos estranegiros aos nacionais nas relações de natureza civil, subordinadas às restrições já apontadas. Mas a capacidade reconhecida aos estrangeiros vai além dos direitos privados, entra na órbita dos direitos públicos, dentro da ampla esfera dos direitos naturais, proclamados pela Assembléia Nacional de 1789.

Apreciável influência desempenhou o Código Napoleão, na Europa. Foi impôsto aos países conquistados e adotado espontaneamente por outros.

Jurisconsultos europeus de alto porte propugnavam a integral equiparação dos estrangeiros aos nacionais na legislação civil dos povos cultos.

Inscreveram essa igualdade os Códigos Civis do Cantão de Berna em 1820, da Holanda em 1839, do Chile em 1855, da Argentina em 1869, da Itália em 1865. Mas o novo Código Civil italiano de 1933 condicionou essa quiparação à reciprocidade e a outras restrições, contrariando aquele "sentimento de humanidade e de fraternidade" que havia ditado o preceito anterior sob a inspiração dos juristas peninsulares e de que tanto se orgulhava GABBA como canon geral proclamado pela lei italiana.

CLOVIS BEVILAQUA escreveu: "As legislações atuais podem ser distribuidas, quanto ao modo por que tratam os estrangeiros, em três categorias: $1^{\circ}$ - As legislações que restringem a capacidade dos estrangeiros, ou fazem depender as suas concessões da reciprocidade. Nêste grupo deve ser incluida o direito de alguns Estados da União norte americana, da França, da Bélgica, da Áustria, etc.; $20^{\circ}$ - As legislações que proclamam a igualdade como regra, mas estabelecem algumas limitações, como a holandesa e a portuguêsa; $3 .^{\circ}$ - As legislações que consagram pura e simplesmente o princípio da igualdade dos nacionais e estrangeiros no círculo das relações jurí- 
dicas de ordem privada". ("Princ. Elemt. de Dir. Int. Priv. ${ }^{0 ",}$ de $1944, \S 23)$.

Seria fastidioso enumerar os dispositivos dos Códigos de tantas nações, a respeito.

Quanto ao Brasil, veremos a seguir qual sua posição, antes e agora.

8. De alta significação para a história política do nosso país constituiu a abertura dos portos do Brasil ao comércio estrangeiro, em 1808, pelo Príncipe Regente de Portugal, logo que aportou a estas plagas, vindo de mudança para a Colônia em consequência da invasão do exército de Napoleão naquele país.

Proclamada a Independência do Brasil, em 1822, a sua Constituição Política de 1824 não cuidou expressamente dos direitos dos estrangeiros. Seu art. 179 de declaração de direitos, através de 35 itens, garante "a inviolabilidade dos direitos civis e políticos dos cidadãos brasileiros, que tem por base a liberdade, a segurança individual e a propriedade". Mas permitiu-se a naturalização dos estrangeiros (art. $6^{\circ}$ ).

No decorrer da vida do Império, até 1889, como mostra TEIXEIRA DE FREITAS, a legislação era liberal para com o estrangeiro, mormente na esfera dos direitos civis, em que não havia disposições restritivas, a não ser no caso de locação de serviços, motivadas pela transitória necessidade da colonização ("Consol. das Leis Civis", 3. ${ }^{\text {a }}$ ed., pág. 137da Intr. e arts. 679 e segs). RODRIGO OCTAVIO enumera as pequenas restrições existentes no "Direito do Estrangeiro no Brasil", pág. 135, Rio, 1909.

Sobrevindo a República, a sua primeira Constituição, de 1891, revelou acentuado espírito liberal, ao assegurar, no art. 72 , "a brasileiros e estrangeiros residentes no país a inviolabilidade dos direitos concernentes à liberdade, à segurança individual e à propriedade" nos têrmos em que a seguir declara, 
em 31 parágrafos. Para impressionante confronto posterior, convém assinalar que apenas uma restrição expressa se encontra no art. 13, § único, ao dispor que "a navegação de cabotagem será feita por navios nacionais", tendo em vista, como faz ver seu primeiro comentador, JOÃO BARBALHO, dar incremento à construção naval e formar no país pessoal apto à navegação, servindo ainda para reserva da tripulação da marinha de guerra. Sua reforma em 1926 creou restrições aos estrangeiros quanto às minas e jazidas minerais ( $\S 17$, letra b) e permitiu a expulsão dos estrangeiros indesejáveis.

Nos dispositivos indicados se encontram previstos, em geral, os direitos públicos sem caráter político.

Relativamente aos direitos civis, pertencentes à órbita do direito privado, para regular os interêsses patriculares das pessoas, o Código Civil, em 1916, estabeleceu, como a Itália e o Chile, a completa equiparação, independente do requisito da residência, ao dispor, no art. $3 .^{\circ}$ : " $A$ lei não distingue entre nacionais $e$ estrangeiros quanto à aquisição e ao gozo dos direitos civis".

Era essa a tradição brasileira, como acentuou TEIXEIRA DE FREITAS, que, no seu célebre "Esbôço" do Código Civil, em 1860, declarou aptos para adquirirem direitos todos os brasieliros e todos os estranegiros, tivessem ou não domicílio ou residência no Brasil (art. 38 ).

Aliás, a expressão "estrangeiros residentes", usada na outorga das garantias constitucionais, há de ser entendida em têrmos, como adiante melhor se verá.

9. Desfrutava o Brasil a terceira década da sua liberal Constituição, para cuja feitura tanto influiu o alto espírito de RUI BARBOSA, quando irrompeu e se desenrolou a primeira Guerra Mundial, finda em 1918. As consequências dessa conflagração se fizeram sentir profundamente na organização social e política dos povos, relevando notar a revolução bolchevista na Russia, com influência socializante no mundo inteiro, 
a par de intenso surto de progresso econômico em tôda parte, inclusive no Brasil, onde, como em outros países, se operou desusada reação nacionalista.

Os abalos políticos de $22,24,30$, e 32 , pondo fim à chamada "república velha" e reestruturando de novo o país políticamente, geraram a recrudescência do, por assim dizer, espírito nativista. E a Constituição de 1934, votada pela Assembléia Nacional, assim como a Carta outorgada em 1937, bem refletiram essa nova tendência, que punha em cheque os princípios liberais antes proclamados. Não vamos porém deter-nos na apreciação dos dispositivos de ambas essas leis básicas, que não mais vigoram.

0 avassalante cataclisma da segunda guerra mundial, terminada em 1945, passou.

A última Constituição do Brasil, promulgada a 18 de setembro de 1946, seguiu, com atenuações, a orientação de restrição aos direitos dos estrangeiros, a par da fertil legislação ordinária que a antecedeu em igual sentido e expressa em decretos-leis, além de outras leis de existência mais antiga.

Em face da Constituição de 1946, documento básico de maior relêvo para aferir melhor o assunto, são de assinalar as restrições a seguir.

a) - É exigida a condição de brasileiro nato para ser:

Presidente da República (art. 80, n. $^{\circ} \mathrm{I}$ );

Deputado ou Senador ao Congresso Nacional (atr. 38, $\S$ único I) ;

Ministro de Estado (art. 90, § único, I;

Ministro do Supremo Tribunal Federal (art. 99) ;

Ministro do Tribunal Federal de Recursos (art. 103);

Procurador Geral da República (art. 126).

b) - Será prestada por brasileiro nato a assistência religiosa às fôrças armadas. 
c) - A navegação de cabotagem para o transporte de mercadorias é privativa dos navios nacionais, salvo caso de necessidade pública. $\mathrm{E}$ devem ser brasileiros natos os proprietários, armadores e comandantes dos navios nacionais, bem como dois têrços, pelo menos, dos seus tripulantes (art. 155 e $\S$ único).

d) - É vedada a propriedade de emprêsas jornalísticas, sejam políticas ou simplesmente noticiosas, assim como a de radiodifusão, a sociedades anônimas por ações e a estrangeiros. Nem êsses, nem pessoas jurídicas, excetuados os partidos políticos nacionais, poderão ser acionistas das sociedades anônimas proprietárias dessas emprêsas. A brasileiros-natos (art. 129, ns. I e II) caberá exclusivamente a responsabilidade principal delas e a sua orientação intelectual e administrativa. (art. 160).

e) - As autorizações ou concessões federais para aproveitamento dos recursos minerais e de energia hidráulica serão conferidas exclusivamente a brasileiros ou a sociedade organizada no país (art. $153, \S 10^{\circ}$ ).

f) - Matérias que as Constituições ou as leis anteriores regulavam expressamente, exigindo a condição de brasileiro ou de brasileiro nato, foram deixadas ao critério do legislador ordinário, como: a) o regime dos bancos de depósito, das emprêsas de seguro, de capitalização e de fins análogo (art. 149) ; b) o regime das emprêsas concessionárias de serviços públicos, federais, estaduais e municipais (art. 151) ; c) o exercicio das profissões liberais e a revalidação de diploma expedido por estabelecimento estrangeiro de ensino (art. 161). Permanecem assim as restrições existentes na legislação comum, enquanto não forem de novo reguladas, salvo se contrariarem a Constituição.

10. É exigida ainda a condição de brasileiro nato para ser :

a) Ministro togado do Supremo Tribunal Militar (dec.-lei n. ${ }^{\circ} 925$, de 2-12-38, art. $8 .^{\circ}$, § único); 
b) Ministro do Tribunal de Contas (dec.lei n. ${ }^{\circ} 426$, de 12 $-5-38$, art. $\left.3 .^{\circ}\right)$;

c) corretor, seus prepostos e adjuntos da Câmara Sindical da Bolsa de Valores e de Corretores de Fundos Públicos do Rio de Janeiro (Reg. Int. ${ }^{\circ}$, arts. $5 .^{\circ}$, letra a, e 98, , $\$ 1 .^{\circ}$, letra a) ;

d) corretor de navios (decr. 19.009, de 27-11-29, art. $3 .^{\circ}$ );

e) presidente de sindicatos rurais (decr.-lei n. ${ }^{0} 7.038$, de 10-11-44, art. $5 .^{\circ}$, letra c);

f) admitido na classe inicial da carreira de diplomata, exigindo-se igual condição do conjuge, se se tratar de pessoa casada (lei n. ${ }^{\circ}$ 2.171, de 18-1-54, art. $1 .^{\circ}$ );

11. Impõe-se a condição de brasileiro, mesmo naturalizado para:

a) ser funcionário público (Const., art. 184, e lei n. ${ }^{\circ} \ldots$ 1.711, de 28-10-52, art. 22) ;

b) negócio de compra e venda de títulos da dívida pública da União, dos Estados e dos Municípios, quanto ao proprietário, se se tratar de firma individual, ou dos sócios, quotistas ou acionistas e diretores ou gerentes, se de sociedade (decr.-lei $\mathrm{n}^{\circ}$ 3.545 , de $22-8-41$, art. $2 .^{\circ}$ ) ;

c) ser corretor de mercadorias no Distrito Federal (decr. n. ${ }^{\circ} 20.881$, de 30-12-31, art. 21) ;

d) ser leiloeiro (decr. n. ${ }^{\circ}$ 21-981, de 19-10-32, art. $2 .^{\circ}$ ) ;

e) ser despachante aduaneiro (decr.-lei n. ${ }^{\circ} 4.014$, de ... 13-1-42, art. 19, letra a);

f) ser tradutor público e intérprete comercial (decr. $n .^{\circ}$ 13.60) de 21-10-43, art. $3 .^{\circ}$, letra a);

g) inscrever-se na Ordem dos Advogados do Brasil, como advogado, para exercer a profissão, admitindo-se também os estrangeiros em caso de reciprocidade (decr. n. ${ }^{\circ} 22.478$, de ... 
20-2-33 art. 13, n. ${ }^{\circ}$ II), bem assim inscrever-se como provisionado ou solicitador (lei . $^{\circ} 161$, de $31-12-35$, art. $3 .^{\circ}$, letra a, e lei n. ${ }^{\circ} 794$, de $29-8-49$, arts. $4 .^{\circ}$ e $5 .^{\circ}$ ) ;

h) exercer funções ou cargos públicos ou emprêgos dos Estados ou Municípios, ou de entidades por êles criadas ou mantidas ou de cuja manutenção sejam responsáveis (lei n..$^{\circ} 1.202$, de 8 de abril de 1939).

12. Outras leis federais exigem, para a investidura em função pública, a qualidade de brasileiro nato ou naturalizado, seguindo a mesma orientação os Estados e Municípios, na conformidade dos principios constitucionais da União e dos preceitos de sua legislação ordinária, notadamente quanto aos cargos de magistratura, ministério público e representação popular.

Tais restrições impostas dêsse modo ao estrangeiro, para o exercício de funções públicas ou de munus público, são antes de caráter político, no amplo sentido, visando ao melhor resguardo dos negócios do Estado. Não afetam os direitos públicos referentes à liberdade e outros nem certos direitos privados na ordem civil. São tais restrições também frequentes em outros países.

Sob o critério do interêsse mais visceralmente nacional, as limitações atingem às vezes os interêsses privados, como nos casos de explorações de recursos minerais e de energia hidráulica, de propriedade de emprêsas jornalísticas e de radiodifusão, e outros, ditados por uma razão superior do Estado.

13. No vasto repositório da legislação brasileira encontram-se ainda muitas leis restringindo os direitos do estrangeiro ou limitando sua atividade, como se verá a seguir.

a) - "O Govêrno Federal poderá expulsar do território nacional o estrangeiro nocivo à ordem pública, salvo se o seu cônjuge fôr brasileiro e se tiver filho brasileiro (nato), dependente da economia paterna" (art. 143 da Const.)

b) - "A vocação para suceder em bens de estrangeiro 
existentes no Brasil será regulada pela lei brasileira e em benefício do cônjuge ou de filhos brasileiros sempre que lhes não seja mais favorável a lei nacional do de cujus". (art. 165 da Const.)

c) - "É proibida a concessão da suspensão condicional da pena imposta aos estrangeiros que se encontrem no território nacional em caráter temporário". (Decr.-lei n. ${ }^{\circ} 4.865$, de ... 23-10-42)

d) - Constitui contravenção penal, punida com prisão simples de três mêses a um ano, "exercer, no território nacional, atividade remunerada o estrangeiro que nêle se encontre como turista, visitante ou viajante em trânsito" (Lei n. ${ }^{0} 3.688$, de 3-10-41, art. 69).

e) - Os estrangeiros fixados no território nacional e os que nêle se achem em caráter temporário não podem exercer qualquer atividade de natureza política nem imiscuir-se direta ou indiretamente nos negócios públicos". (Lei n. ${ }^{\circ} 383$, de .... 18-4-38 e decr.-lei n. ${ }^{\circ} 3.016$, de 24-8-38, contendo ainda aquela muitas outras disposições proibitivas de ordem política)

f) - Pertencerá, em sua totalidade, a pessoas físicas de nacionalidade brasielira, o capital das sociedades anônimas para operações de seguros privados (Decr.-lei n. ${ }^{0} 2.603$, de 7-3-40)

g) - A nacionalização da indústria de refinação do petróleo importado ou de produção nacional requer: "I - capital social constituido exclusivamente de brasileiros natos, em ações nominativas; II - direção e gerência, confiadas exclusivamente a brasileiros natos, com participação obrigatória de empregados brasileiros, na proporção estabelecida pela legislação do País." (Decr.-lei n. ${ }^{\circ} 395$, de 29-4-38, art. $3 .^{\circ}$ )

h) - Igualmente, para funcionamento das sociedades de mineração de petróleo e gases naturais, faz-se mister a prova da nacionalidade brasileira, pelos sócios ou acionistas, exigindo-se também a nacionalidade brasileira do requerente de pes- 
quiza das jazidas de petróleo e gazes naturais (Decr.-lei $n .^{0} \ldots$ 3.236 , de $7-5-41$, arts. $3 .^{\circ}$ a $7 .^{\circ}$ )

i) - A concessão sôbre o serviço de loterias só será outorgada a firma composta de sócios brasileiros, excluidas as sociedades anônimas cujas ações não sejam tôdas nominativas (Decr.-lei n. ${ }^{\circ}$ 6.259, de 10-11-44, art. $7 .^{\circ}$ )

j) - Na cautio judicatum solvi, a obrigação não é só para o estrangeiro, pois abrange também o nacional nas mesmas condições, na conformidade do art. 67 do Código do Processo Civil, assim: "O autor nacional ou estrangeiro, que residir fora do País ou dêle se ausentar durante a lide, si não tiver bens imóveis que assegurem o pagamento das custas, prestará caução suficiente, quando o réu o requerer".

k) - A propósito do item antecedente, é de notar que, competindo aos Estados da federação decretar impostos sôbre transmissão de propriedade causa mortis, costumam êles sobrecarregar a quota do herdeiro, legatário ou donatário, domiciliado no estrangeiro, isto é, sem atender à condição de ser nacional ou estrangeiro, com um acréscimo além das taxas normais, o qual, o Paraná, é de vinte por cento sôbre o valor da quota, salvo se o beneficiário da herança "estiver em serviço público da União, do Estado ou dos seus Municípios". (Decr.-lei 658, de 28-6-47, art. 77)

14. Os casos apontados se apresentam de mais fácil menção porque constituem limitações sumárias e expressas, de interêsse nacional. Entretanto, na regulamentação da vida do estrangeiro e de suas atividades, mormente no domínio econômico, há uma vasta legislação, compreendendo: a) - a naturalização, sua aquisição, seus efeitos, sua perda, conflitos sôbre nacionalidade e convenções a respeito; b) - entrada, registro e permanência de estranegiros no País, passaportes; c) - adaptação ao meio nacional dos brasileiros descendentes de estrangeiros; d) - aplicação territorial da lei penal, extradição e expulsão; e) - execução de sentença estrangeira civil, comercial e criminal e cumprimento de cartas rogatórias; f) - matrícu- 
la, inscrição de firma individual, ou arquivamento de contratos e quaisquer outros documentos no Registro do Comércio; g) - sociedades anônimas ou companhias estrangeiras para funcionar no Brasil; h) - concessões de terras e vias de comunicações, transações imobiliárias, bem como o estabelecimento de indústria e comércio de estranegiro na faixa de fronteiras; i) - aforamento de terrenos de marinha; j) - privilégios de invenção, marcas de indústrias e comércio, nome comercial, título de estabelecimento, insígnias ou expressões ou sinal de propaganda; $\mathrm{k}$ ) - tributação das pessoas físicas e jurídicas para pagamento do impôsto de renda; 1) — normas gerais e especiais de tutela do trabalho, nacionalização do trabalho, organização sindical, lock-out e greve; m) - caça e pesca; n) - pagamentos em moeda estrangeira (cláusula ouro); o) - operações de câmbio; p) — transporte marítimo, terrestre e aéreo etc.

15. As limitações aos direitos dos estrangeiros o Estado estabelece justificadamente, para auto-defesa, temendo o enfraquecimento de sua autoridade por interferência, às vezes malsã, de elementos alienígenas, ou visando à melhor proteção dos nacionais, nos seus interêsses.

Se encararmos a multidão e a complexidade de relações de que têm a faculdade de participar, ou de que, de fato, participam os estrangeiros, as restrições, relativamente, não avultam.

Há direitos fundamentais, há cânones de igualdade civil, há normas de ordem privada que se aplicam indistintamente a nacionais e estrangeiros, residentes ou não.

CARLOS MAXIMILIANO, em comentário ao art. 141 da Constituição, assinala: "Existe igualdade unicamente entre nacionais e estrangeiros residentes no pais. ... Privado de residência o alienígena, desaparece a equiparação ao nacional e extinguem-se os direitos correspondentes". ("Com. à Const. Bras. de $1946 ", 4 .^{a}$ ed., $1 .^{\circ}$ v., pág. 32 )

Entretanto, a afirmação "extinguem-se os direitos corres- 
pondentes" do eminente mestre não pode ser aceita com êsse sentido absoluto. Pois ficaria parecendo, a contrario sensu, que os estrangeiros não residentes no Brasil deixariam de ser amparados quanto a certos direitos públicos sem caráter político ou aos direitos civis essenciais, todos considerados fundamentais, preexistentes à organização do Estado e, portanto, impostergáveis, como a liberdade física, a liberdade de consciência, a liberdade de manifestação de pensamento, a liberdade de culto, o direito de propriedade, o direito de constituir família legítima, o direito à inviolabilidade do lar, o direito ao sigilo da correspondência, o direito de contratar, o direito de instrução, o direito de assistência, o direito de reunião. A êsses direitos clássicos se juntam modernamente os direitos socialistas, concretizados na legislação trabalhista, ante as conquistas realizadas, seja através da "revolução pela violência", como se verificou na Russia, seja através da "revolução pelo consentimento", no autorizado conceito de $\mathrm{H}$. LASKI, à margem do pensamento de MARX, quando êste, preconisando a passagem do capitalismo para o socialismo, doutrinou: "Mas nós não afirmamos que o processo de alcançar êste fim seja o mesmo em tôda parte. Sabemos que as instituições, maneiras e costumes dos diversos países devem ser levados em conta, e não negamos que há nações como a Inglaterra e a América, e... poder-se-ia mesmo acrescentar a Holanda, onde o trabalhador pode atingir êste objetivo por meios pacíficos. Entretanto, nem em todos os países, deve ser êste o processo". (apud PINTO FERREIRA, "O Dir. Const. Mod.", Rio, 2. ${ }^{a}$ ed., 1951, pág. 600)

São as duas correntes que hoje se distinguem sob as formas de socialismo proletário e socialismo liberal.

O mesmo citado autor brasileiro, louvando-se em recentes indagações do direito político, procedidas por excelsas figuras do pensamento jurídico contemporâneo, chega à discriminação dos direitos fundamentais em absolutos e relativos, classificando entre aqueles a liberdade do domicílio e de correspondência, e, entre êstes, os direitos de contrato, de propriedade, de comércio e de indústria, valendo conforme a lei ou nos limites da lei, 
"como se vulgarizou na técnica da Constituição de Weimar". (Ob. cit., pág. 505)

16. PONTES DE MIRANDA esclarece: "alguns incisos do art. 141 são acima do Estado, e as próprias Assembléias Constituintes, em revisão, não os podem revogar ou derrogar. Tais incisos são os que mantêm declaração de direitos fundamentais supraestatais. .... Os direitos supraestatais são, de ordinário, direitos fundamentais absolutos. Não existem conforme os cria ou regula a lei; existem a despeito das leis que os pretendam modificar ou conceituar. Não resultam das leis, precedem-nas; não têm o conteúdo que elas lhe dão, recebem-no do direito das gentes." ("Com. à Const. de 1946"), $1 .^{a}$ ed., 3. ${ }^{\circ}$ v., pág. 149). E adiante: "há preceitos que independem da afirmação inicial sôbre cidadãos e estrangeiros residentes no Brasil e independem pela própria natureza das coisas: são as garantias institucionais; e as garantias institucionais são desligadas da subjetividade eventual. Assim, o direito de propriedade é garantido a favor do estrangeiro não-residente no Brasil" (pág. 164)

Dentro da comunidade jurídica internacional, segundo a concepção de SAVIGNY para justificar a aplicabilidade do direito estrangeiro, no âmbito do direito internacional privado, há que atender às considerações já indicadas e a outras ainda, levando em conta a nacionalidade ou o domicílio das pessoas para certos direitos, como de família e sucessões, estado e capacidade, e as regras referentes às coisas móveis e imóveis, às obrigações, à forma dos atos etc.

17. SANCHES DE BUSTAMANTE, notável internacionalista cubano, estabelece uma classificação sistemática dos direitos humanos, dividindo-os em duas classes: sociais e politicos. Os sociais se referem ao grupo de pessoas que compõem a sociedade civil ou estão com ela em relações pessoais e econômicas. Subdivide os sociais em voluntários ou pessoais, conforme afetem só as pessoas, e necessários ou estáticos, pela uniformidade em sua origem e em suas consequências. Igualmente, subdivide os políticos em públicos e cívicos, porque aqueles 
conferem a todos os homens as faculdades e a proteção necessárias à vida livre como a inviolabilidade do domicílio, ao passo que êstes outorgam a faculdade de contribuir para a organização da sociedade, como seja o sufrágio (votar e ser votado). E observa: "Facilmente se compreende que no puede negar-se al extranjero, como miembro de la comunidad jurídica internacional ni como ser cosmopolita, el goce e el ejercício de los derechos sociales que hemos llamado voluntarios ni el desfrute de los de indole politica que especialmente denominamos publicos." ("Derecho Int. Privado", 3. ${ }^{a}$ ed., Habana, tomo I, pág. 131-32)

Através dêsse ligeiro resumo, percebe-se a lição do jurista cubano no sentido de declarar fundamentais no homem, sem distinção de nacionalidade, os direitos voluntários, ou sejam os privados essenciais, como o de contratar, e os públicos, participando da índole política, em sentido amplo, como a liberdade física, a de pensamento, a de culto, a de reunião.

18. EDUARDO ESPINOLA, emérito internacionalista pátrio, prefere chamar a êstes últimos de "direitos públicos não políticos", para serem exercidos quer pelos nacionais, quer pelos estrangeiros, embora êstes não sejam residentes no país, assim resumindo seu pensamento, a respeito: “Em síntese, em face do direito pátrio, os estrangeiros residentes no país são equiparados aos brasileiros, no tocante ao gozo e exercício dos direitos públicos não políticos; os estrangeiros não-residentes são reconhecidos capazes de modo geral, mas podem ser submetidos a restrições mais ou menos rigorosas por leis especiais". ("Dir. Int. Privado", Rio, 1925, pag. 137-8). E nota que "onde porém se acentua o princípio da igualdade de nacionais e estrangeiros, é no departamento dos direitos privados, não se fazendo nenhuma distinção entre estrangeiros residentes $e$ não-residentes no Brasil". (pág. 142)

19. O Código de Direito Internacional Privado (Código Bustamante), aprovado, a 18 de fevereiro de 1928, na Conferência Interamericana de Havana e ratificado por quinze países americanos, entre os quais o Brasil, onde foi promulgado 
pelo decreto $n .^{\circ} 18.871$, de 13 de agosto de 1939 , traz no seu título preliminar, de início, as seguintes regras gerais.

"Art. $10^{\circ}$ - Os estrangeiros que pertençam a qualquer dos Estados contratantes gozam, no território dos demais, dos mesmos direitos civis que se concedam aos nacionais.

Cada Estado contratante pode, por motivo de ordem pública, recusar ou sujeitar a condições o exercício de determinados direitos civis aos nacionais dos outros, e qualquer dêsses Estados pode, em casos idênticos, recusar ou sujeitar a condições especiais o mesmo exercício aos nacionais do primeiro.

Art. $2 .^{\circ}$ - Os estrangeiros que pertençam a qualquer dos Estados contratantes gozarão também, no território dos demais, das garantias individuais idênticas às dos nacionais, salvo as restrições que em cada um estabeleçam a Constituição e as leis.

As garantias individuais idências não se estendem ao desempenho de funções públicas, ao direito de sufrágio e a outros direitos políticos, salvo disposição especial da legislação interna".

A consideração de serem residentes ou não-residentes deixou de ser levada em conta. 0 art. $2 .^{\circ}$ ressalva as restrições estabelecidas e os direitos políticos, exceto em casos permitidos. A última parte da alínea segunda do art. $10^{\circ}$ fixa um critério de reciprocidade inversa, isto é, não para permitir concessões mútuas, mas para recusas e limitações recíprocas, a feição quase de represália.

$\mathrm{Na}$ mesma Conferência Interamericana de Havana, os Estados dela participantes assinaram, a 20 de fevereiro de 1928, a Convenção sôbre Condição dos Estrangeiros, em apenas nove artigos, ratificada por treze países, entre os quais o Brasil, onde foi promulgada pelo decreto $n .^{\circ} 18.956$, de 22 de outubro de 1929. 
Expressivo o art. $5 .^{\circ}$ dessa Convenção, a seguir, com os necessários grifos:

"Art. 5..$^{\circ}$ Os Estados devem conceder aos estrangeiros domiciliados ou de passagem em seu território tôdas as garantias individuais que concedem aos seus próprios nacionais e o goso dos direitos civis essenciais, sem prejuizo, no que concerne aos estrangeiros, das prescrições legais relativas à extensão e modalidade do exercício dos ditos direitos e garantias".

Não se cogita aí de limitar a concessão aos estrangeiros residentes, porque mesmo aos em trânsito ela se estende

0 reconhecimento da personalidade jurídica do estrangeiro para o gozo dos direitos públicos não políticos e dos direitos civis essenciais constitui "um princípio corrente da civilização jurídica do Estado moderno", na expressão de MACHADO VILELA, ou "le minimum de droits que comportent les lois de l'humanité", na frase de NIBOYET.

Nêsse mínimo de direitos públicos se acha incluido o de pleitear perante os tribunais, reconhecido universalmente.

Tal critério liberal, humano, moderno, atendendo às exigências da comunidade jurídica internacional, alarga o círculo de proteção, abrangendo mesmo o estrangeiro que não haja estado no país a cujo direito se abriga.

20. EDUARDO ESPINOLA e ED. ESPINOLA FILHO, encarando, com a visão de internacionalistas, a condição do estrangeiro assim definida, prestam êste judicioso esclarecimento quanto ao amparo dos direitos civis essenciais, isto é, de família, patrimoniais reais, patrimoniais pessoais ou obrigações e contratos, e direitos de sucessão: "É bem de ver que se não confunde êsse reconhecimento com o problema da lei competente para regular o direito reconhecido. Assim, por ex., a lei do Estado, onde se encontra o estrangeiro, reconhece que êle pode 
casar-se perante as autoridades locais. Outra lei do mesmo Estado (norma de direito internacional privado determina que lei (se a nacional do estrangeiro, a do domicílio, a territorial) deve ser observada quanto aos impedimentos matrimoniais, quanto ao regime de bens etc." ("Trat. de Dir. Civil Bras. ${ }^{\text {, }}$ vol. VI, pág. 256 e 392).

Além das restrições já assinaladas em tópicos anteriores do presente estudo, limitações podem surgir na aplicação da lei competente para regular o direito reconhecido. No exemplo figurado pelos citados autores, se a lei competente fôr de outro país que não aquele em que o casamento vai realizar-se, só poderá ser ela aplicada se não ofender à ordem pública internacional. Assim se os impedimentos dirimentes são ditados pela lei pessoal (nacionalidade ou domicílio) e entre êles se encontra a proibição de casamento entre um homem de côr preta e mulher de côr branca, não será atendido tal impedimento no país da realização alheio à discriminação racial. Aliás no Brasil digamos de passagem - constitui preceito territorial a aplicação da lei brasileira quanto aos impedimentos dirimentes, nos casamentos realizados no país (art. $7 .^{\circ}, \S 1 .^{\circ}$ da L. de I. do Cod. Civil).

21. De tudo quanto ficou examinado com relação ao Brasil, evidencia-se não corresponderem à realidade de sua organização jurídico-constitucional nem o art. 141 (caput) da Constituição Brasileira de 1946, limitando a proteção aos "estrangeiros residentes", consoante prática das anteriores Constituições republicanas, de 1937, 1934 e 1891, nem o art. 3. do Código Civil Brasileiro, quando peremptòriamente declara: “ $a$ lei não distingue entre nacionais e estrangeiros quanto à aquisição e ao gozo dos direitos civis".

De jure constituendo, impõe-se, oportunamente, a revisão de tais textos para adaptá-los à situação de direito e de fato dentro da comunidade jurídica internacional, no sentido ampliativo, e ainda de conformidade com os interêsses da comunhão nacional, no sentido restritivo. 
Nos meados do século dezenove, como conquista gloriosa às concessões paulatinamente outorgados aos estrangeiros $\mathrm{e}$ graças à pregação doutrinária de juristas e estadistas do alto porte de MANCINI, na Itália, chegou-se a inscrever no Código Civil dêsse país, em 1865, o preceito absoluto do art. $3 .^{\circ}$ assim: "Lo straniero é ammesso a godere dei diritti civili attribuiti ai cittadini".

Já o Código Civil do Chile de 1855, cuja feitura se deve quase inteiramente à poderosa cerebração de ANDRÉ BELLO, incluíra igual regra no art. 57: "La lei no reconoce diferencia entre el chileno y el extranjero en quanto a la acquisición y goce de los derechos civiles que regla este Código".

Mas o legislador italiano de 1939 voltou atraz, pondo freios à amplitude do dispositivo há pouco citado. $\mathrm{E}$ estabeleceu, no art. $6 .^{\circ}$ : "Lo straniero é ammesso a godere dei diritti civili attribuiti al cittadino a condizione di reciprocitá e salve disposizioni con tenute in leggi speciali".

Afora a condição de reciprocidade, lamentavelmente indicativa de retrocesso na marcha do liberalismo para fortalecer cada vez mais a comunidade internacional, a ressalva "salvo as disposições contidas em leis especiais" - atende à realidade das limitações existentes. Também a Constituição Alemã, consoante ficou atras assinalado, assegura aos seres humanos os direitos fundamentais "nos limites da lei", formula como aquela, mais racional.

22. Depois da Declaração de Direitos da Virgínia, em 1776, nos Estados Unidos, e da Declaração dos Direitos do Homem e do Cidadão, publicada no preâmbulo da Constituição da França de 1793, em plena Revolução, monumentos políticos que bem refletiram o influxo da tradição liberal da Inglaterra e os ensinamentos dos pensadores e juristas da época, através de suas obras, como "Le Contract Social" de ROUSSEAU, a Enciclopédia Francêsa de DIDEROT e D'ALAMBERT, os países que, nos séculos XIX e XX, se organizaram constitucionalmente, não deixaram de inserir, no seu estatuto básico, preceitos 
da mesma natureza e significação daqueles proclamados pelos três mencionados Estados líderes da democracia e da liberdade.

A última Constituinção do povo Francês, de 1946, contém esta Declaração de suma expressão: "Il réaffirme solennellement les Droits et les Libertés de l'Homme et du Citoyen consacrés par la Déclaration des Droits de 1789 et les principes fondamentaux reconnus par les lois de la République".

A IX Conferência Interamericana reunida na cidade de Bogotá aprovou, em maio de 1948, a Declaração Americana dos Direitos e Deveres do Homem, condensando, com as discriminações necessárias, todos os postulados modernos de referência aos direitos fundamentais da pessoa humana e seus deveres, na esfera internacional.

Há porém um monumento humano, social, jurídico e político, também recente, que supera quantas obras semelhantes se possam invocar de superior. É a Declaração Universal dos Direitos do Homem, aprovada e proclamada pela Assembléia Geral das Nações Unidas, a 6 de dezembro de 1948. A Declaração da O. N. U., orgão do maior prestígio internacional, surgida num ciclo novo da história da humanidade e imbuida de caráter universal, representa a última conquista na defesa e no respeito aos interêsses humanos. Do conjunto de suas normas exemplares, embora sem o sêlo ainda da promulgação mediante lei interna, é notável a fôrça moral e jurídica que delas irradia e as impõe, soberanamente, a todos os povos.

As liberdades fundamentais, as garantias individuais, os direitos civis essenciais estão alí contidos como tributo de resfeito ao bem estar e à dignidade humana. Absoluta igualdade para fruição dêsses bens naturais. Direito à vida, à liberdade, à segurança pessoal; direito de recorrer aos tribunais; direito de respeito à vida privada do homem, sua família, seu lar, sua correspondência, sua honra e sua reputação; direito de locomover-se, de sair do país e de a êle regressar; direito de asilo; direito de ter uma nacionalidade e de trocar de nacionalidade; direito de casar por livre vontade, constituir família, com igual- 
dade de direitos para os cônjuges durante o matrimônio e no momento de sua dissolução; direito à propriedade; direito à liberdade de pensamento, de expressão, de consciência e de religião; direito à liberdade de reunião e de associação; direito ao trabalho, à sua livre escolha, a condições equitativas e favoráveis de trabalho, à proteção contra o desemprêgo, à igualdade do salário por trabalho igual, a uma remuneração justa, para assegurar uma existência de acôrdo com a dignidade humana; direito ao descanso, ao emprêgo útil do tempo livre, a um limite razoavel de duração do trabalho e a férias periódicas remuneradas; direito a um nível de vida adequado, ao seguro social, à assistência à maternidade e à infância, à instrução gratuita, pelo menos no gráu elementar, que deverá ser obrigatória; direito de participar livremente da vida cultural da comunidade, de gozar as artes e de desfrutar os benefícios que resultem do progresso científico; direito, enfim, a que se estabeleça uma ordem social e internacional, na qual sejam plenamente efetivados os direitos e liberdades enunciados.

Não caberia também aqui a distinção entre os nacionais e estrangeiros residentes ou não residentes no País, para fruição dos direitos mencionados na portentosa Declaração da O.N.U., quer os públicos não políticos, quer os civis, nela incluidos. 